\title{
Pronominal Subject Clitics in Igbo
}

\author{
Ogbonna Anyanwu \\ Department of Linguistics and Nigerian Languages, University of Uyo, Nigeria \\ Email: ogbonnaanyanwu@yahoo.com
}

\begin{abstract}
Pronominal elements in Igbo have been categorized into two types; the independent ones and the dependent, short, weak ones. Whereas the independent pronominal elements can occur both at the subject and object positions, the so-called dependent ones (which have also been analyzed as resumptive pronouns (Uwalaka, 1995)) are restricted to the subject position. This paper seeks to examine the dependent pronominal elements in Igbo and it has reanalyzed them as pronominal subject clitics (PSCs) based on certain syntactic evidence such as pronouns as second objects, pronouns in relation to prepositions, pronouns and enclitics, reflexive constructions (Nwaozuzu, 2007). Other syntactic evidence which strengthen our analysis of the dependent pronouns as PSCs are strict adjacency to a main or auxiliary verb, modification facts, topicalization, clefting, emphasis, coordination. Furthermore, based on evidence from Igbo causative construction, the PSCs have been analyzed as occupying pro-argument positions in the constructions where they appear. The paper therefore, concludes that the Igbo PSCs do not constitute prosodically autonomous lexical entities; rather they are phonologically deficient and dependent on adjacent lexical items. This study is based on a database including both actual and potential expressions, which standard Igbo speakers find to be in consistent with their language rules. The approach, which has been adopted for the analysis is purely descriptive. Igbo is the third largest indigenous language in Nigeria. It is spoken indigenously in the South-Eastern states of Abia, Anambra, Ebonyi, Enugu and Imo.
\end{abstract}

Index Terms — clitic, prononominal, resumptive, causative, pro, affixal

\section{INTRODUCTION}

The two categorizations of pronominal elements in Igbo are the independent pronouns mí(ú) 'I', gí 'you (sg)', únù 'you (pl)', yá 's/he' and há 'they' and the dependent, short, weak pronouns 1̂li ‘you (sg)', a/e 'some person(s)' and ó/ó 's/he' (Green and Igwe, 1963,Emenanjo, 1978). Thus, the dependent, short and weak pronouns in Igbo are three, each of the weak pronouns has two forms and each form is conditioned by the [ATR] feature of an immediately following verbal element. The pronominal elements in Igbo can also be categorized into person-number specific and non-person number specific. With the exception of a/e 'some person(s)', which is non-person-number specific (it can refer to all persons), the other pronominal elements are person-number specific. In table I below, the PSCs are shown together with their substantive (independent) counterparts.

TABLE 1.

PERSONAL SUBJECT PRONOUNS AND PRONOMINALSUBJECT CLITICS IN IGBO

\begin{tabular}{|l|l|l|}
\hline Person/Number & Independent/Substantive Pronouns & $\begin{array}{l}\text { Dependent/Non- } \\
\text { substantive/PSCs }\end{array}$ \\
\hline $1^{\text {st }}$ singular & $\mathrm{m}(\mathbf{u})$ & - \\
\hline $1^{\text {st }}$ plural & ányì & - \\
\hline $2^{\text {nd }}$ singular & ǵi & $\mathrm{i} / \mathrm{i}$ \\
\hline $2^{\text {nd }}$ plural & únù & - \\
\hline $3^{\text {rd }}$ singular & yá & $\mathrm{o} / \mathrm{o}$ \\
\hline $3^{\text {rd }}$ plural & há & - \\
\hline non-definite & - & $\mathrm{a} / \mathrm{e}$ \\
\hline
\end{tabular}

However, the categorial status of the dependent, short, weak forms, í/1 'you (sg)', a/e 'some person(s)' and ó $/ \mathrm{o}$ ' $s / \mathrm{he}$ ' has not been given a uniform account. Whereas Green \& Igwe (1963) and Emenanjo (1978) refer to them as independent pronouns, Uwalaka (1995) analyzes them as resumptive pronouns. However, given the restricted subject position of occurrence of the pronominal forms and their phonological conditioning by an adjacent verbal element, their status/analysis as either dependent pronouns or resumptive pronouns does not seem to reflect their characteristic behaviour.

In this paper, we shall argue, using some syntactic evidence; pronouns as second objects, pronouns in relation to prepositions, pronouns and enclitics, reflexive constructions (Nwaozuzu, 2007), strict adjacency to the main or auxiliary verb, modification, topicalization, clefting, emphasis and coordination that the dependent pronominal elements are pronominal subject clitics (PSCs). As PSCs, they can only occupy pro-argument positions in the constructions where they appear though superficially, they seem to appear at subject argument position. The Igbo PSC, as we shall argue has 
the features of pro in pro-drop languages. We shall attempt to support our position by comparing the Igbo PSC with the pro in some pro-drop languages in addition to evidence from Igbo causative construction. The implication of the analysis being that Igbo should be among the group of pro-drop languages. We shall refer to the independent in pronouns Igbo as substantive pronouns and they can be distinguished from the PSCs in many ways. Though our focus shall be on the pronominal clitics we shall nevertheless, in the course of our discussion, highlight on some of these distinctions.

\section{The IGBo DePENDENT, SHORT AND WEAK PRONOUNS AS PSCS}

Clitics serve as syntactic constituents but are phonologically bound to adjacent elements of lexical categorial status (Borer, 1986). Unlike lexical items clitics do not constitute prosodically autonomous elements and in this respect, they pattern like affixes. However, clitics unlike affixes enjoy a much larger freedom of attachment. They can attach to more than one grammatical category provided that grammatical category is located in the appropriate domain. Clitics straddle the boundaries between words and morphemes and between syntax and morphology. They raise interesting problems for any theory of the interface between syntax and morphology since they are syntactic words and also serve as word parts. Thus, their presence can be explained in terms of syntactic dependencies, though their position follows from morphological rules.

Clitics may be appended at the beginning (proclitic) or at the end (enclitic) of their host. Also a clitic can be a simple clitic or a special clitic (Zwicky, 1977). A simple clitic belongs to the same word class as some independent word of the language that can substitute for it in a syntactic position. A special clitic on the other hand is not a contracted form of self-standing word but a form that can only occur as bound morpheme appended to hosts in certain syntactic contexts (Katamba, 1993). A typical example of a simple clitic is the French singular definite article le or la which is realized as the proclitic l' before hosts which begin with vowels (e.g. l'ami) but as independent words before consonantcommencing hosts. The English genitive is an example of special clitic. Though it does not have a reduced form, it never occurs without being attached to a host.

The dependent, short and weak pronouns in Igbo fall within the category of special clitics since they appear in some special position, at the subject position before verbal elements as proclitics. In the sections that follow, we shall argue for their clitic statuses, as pronominal subject clitics (PSCs). Examples of the PSCs in constructions are given in (1) 1

1a) í-rìrì ńrí.

2sg CL. eat-past food

'You ate food'

b) í-tàrà ánū

2sg CL. chew-past meat

'You ate some meat'

c) ó- rìrì ńrí

3sg CL eat-past food

'S/he ate food.'

d) ọ́-tàrà ánú

3sg CL. chew-past meat

'S/he ate some meat'

e) é-rìrì ńrí

some person (s) CL. eat-past food

'Some person(s) ate food'

\section{SYNTACTIC EVIDENCE FOR THE Clitic STATUS OF THE IGBo PSCS}

Nwaozuzu (2007) extensively discusses one of the pronominal clitics, the so-called Igbo impersonal pronoun 'e/a' and calls it the 'unspecified' pronominal element. Using certain syntactic evidence which, we have outlined below (i-iv), she observes that 'e/a' syntactically behaves differently from the substantive personal pronouns in Igbo.

\section{A. Pronouns as Second Objects of their Verb}

It is only the substantive personal pronouns that can occur as direct or indirect objects of their verbs (2a) and never the 'e/a' (2b-c).
2(a) Òbí nyèrè
há yá
Obi give- rv past $3 \mathrm{pl} 3 \mathrm{sg}$
'Obi gave it to them'
*(c) Òbí nyèrè yá a
Obi give- rv past $3 \mathrm{sg} \mathrm{CL}$
*(b) Òbí nyèrè $\quad$ a yá
Obi give-rv past CL $3 \mathrm{sg}$

\footnotetext{
${ }^{1}$ In the Igbo orthography, the pronominal clitics are written separately form a following verbal element
} 


\section{B. Pronouns in Relation to Prepositions}

Substantive personal pronouns can be preceded by prepositions in Igbo (2d-e) unlike the 'e/a' (cf. 2f).

2(d) Ớ bù̀ nà gí/yá ká Àdá dàbèrè

It be prep. $2 \mathrm{sg} / 3 \mathrm{sg}$ that Ada lean- on -rv benefactive

'It is on you/him (her) that Ada relies /Ada relies on you/him'

2(e) Ớ bù̀ n’ ányị̂lúnù ká Àdá dàbèrè

It be prep. $1 \mathrm{pl} / 2 \mathrm{pl}$ that Ada lean-on rv -benefactive

'It is on us/you (pl) that Ada relies on/Ada relies on us/you (pl)'

$2(\mathrm{f})$ * Ó bù̀ $\mathrm{n}$ ' a ká Àdá dàbèrè

It be prep. CL that Ada lean-on rv- benefactive

C. Pronouns and Enclitics (such as $-k w a,-n u$ )

While the substantive personal pronoun can co-occur with enclitics such as -kwa/nu 'certainly' (cf.2 g (i)-(vi)), the 'e/a' cannot (cf. f (vii)).
2(g) (i) mứ-kwá/nú, 'I certainly'
(ii) gi-kwá/nú 'You (sg) certainly'
(iii) yá-kwá/nụ́ 'S/he Certainly'
(iv) ányịi-kwá/nụ́ 'We Certainly'
(v) únù-kwánú 'You (pl) certainly'
(vi) há-kwá/nụ́ 'They certainly'
(vii) * e/a-kwa/nu?

\section{Reflexive Constructions}

Substantive personal pronouns occur in reflexive constructions (3a-c) unlike 'e/a' (3d-e).
3(a) mú òwéḿ
'I myself'
(b) gí òwégí
'You yourself'
(c) yá òwéyá
'S/he herself/himself'
(d) *é òwé é
$\mathrm{Cl}$ self $\mathrm{CL}$
(e) *á òwé á
CL self CL

On the basis of the observed syntactic differences between the lexical/substantive personal pronouns and the 'e/a', the unspecified personal pronominal element, Nwaozuzu (2007) notes that "it is better to talk of the empty category NP subject verb form (cf.1a-e) rather than... referring to an impersonal pronoun" (p.26.) She further notes that there is no reason to separate ' $\mathrm{e} / \mathrm{a}$ ' from its hosting verb, concluding that 'e/a', the so-called impersonal pronoun in Igbo "could be a remnant of the nominalizer or the nominal marker associated with the Niger Congo group of languages to which Igbo belongs".

It is important to note that the syntactic behaviour of the 'e/a' as observed in (1) is not different from those of the person specific ones (i/i, o/ọ). They are all subject to the above syntactic conditions as outlined by Nwaozuzu (2007) and even much more, as we shall see in the following section, hence our reanalysis of them as clitics

\section{STRENGTHENING EVIDENCE FOR THE Clitic Status OF THE IGbo PSCS}

In this section, we shall examine the following features of the pronominal elements, which provide strengthening evidence of their clitic status. These features are outlined below.

\section{A. Adjacent to Main /Auxiliary Verb}

The PSCs in Igbo must be adjacent to main or auxiliary verbs unlike substantive pronouns and lexical NP subjects, which pattern differently (4a \&b). Jaeggli (1981) has made this same observation about pronominal subject clitics in French.
4 (a) Ó
(* nááni) gàrà áhíá
3sg.CL only go. rv past market

(b) Ézè/ Únù (nááníi) gàrà âhíá

Eze 2pl only go-rv market 
'Only Eze/ you went to market'

\section{B. Modification}

The PSCs always occur on their own without modification while the substantive pronouns can be modified by numerals $(5 \mathrm{a} \& \mathrm{~b})$.

$$
\begin{aligned}
& \text { 5(a) Ó * àtọ kà há chọrò } \\
& \text { 3sg. CL NUM Foc. 3pl want-rv self benefactive }
\end{aligned}
$$

\section{Topicalization}

Unlike both lexical NPs and substantive pronouns, pronominal clitics cannot be topicalized. This accounts for why (6a) is ungrammatical.

6 (a) * Ó, kà Àdá nyèrè -t égō
3sg.CL Foc. Ada give-rv past money

(b) Yá/ Há/ Únù/Ézè, kà Àdá nyèrè -t égō 3sg. 3pl 2pl Eze Foc. Ada give-rv past money 'It is him/they/you (pl)/Eze that Ada gave money'

\section{Clefting}

Whereas substantive pronouns and lexical NPs can be clefted, the pronominal clitics cannot as the following examples show.

7 (a) * Ó bù ó kà Àdá nyèrè -t égō

(b) Ó bù yá/há/únù/ Ézè kà Ádà nyèrè -t égō it be 3sg. 3pl 2pl Eze Foc. Ada give-rv past money 'It was him/ them/ you (pl)/Eze that Ada gave (some) money'

\section{E. Emphasis}

Whenever there is emphasis on the subject, a substantive pronoun is used rather than a PSC (8a \&b).

$$
\begin{array}{cc}
8 \text { (a) * Ó } & \text { bía ! } \\
\text { 3sg.CL come }
\end{array}
$$

(b) Yá/Únù/Há bìa ! 3 sg. $2 \mathrm{pl} 3 \mathrm{pl}$ come

'Let him/you/you (pl)/them come'

\section{F. Coordination}

A PSC cannot be conjoined with a substantive pronoun or lexical NP. This is unlike the substantive pronouns and lexical NPs that can be conjoined with each other (9a, b \& b).

$$
\begin{aligned}
& 9 \text { (a) } * \underset{1}{0} \text { nà Àdá bìarà } \\
& 3 \text { s.g.CL and Ada come -rv past }
\end{aligned}
$$

(b) Yá nà únù bìàà 3 sg. and $2 \mathrm{pl}$ come $-\mathrm{rv}$ past 'S/he and you (pl) came'

(b) Yá/há nà Àdá/gíi bìàrà $\mathrm{S} /$ he and Ada you come -rv past 'S/he and Ada/you came'

In addition to the above syntactic evidence, there is also a phonological one; the [ATR] vowel quality of pronominal clitics is conditioned by the [ATR] vowel quality of a following verbal element. This can be observed in all the examples cited.

It is however worthy of note that what we are calling PSCs have also been referred to as resumptive pronouns by Uwalaka (1995). According to her, the resumptive pronouns are fully grammaticalized in Igbo occurring in interrogatives (10), left-dislocated structures (11), purpose clauses (12) and complement clauses (13).

(10) Ńgó́zíi, ò̀ gàrà áhịá?

Ńgózí 3sg go-past market

'Did Ngozi go to market?'

(11) Òbíi, ó $i_{i}$ bù̀ nwókē 
Òbí 3sg be man

'(As for) Obi i he is a man'

(12) Ngọ́zíi bìàà [CP kà [IP ố hụ há ]]

Ńgózí come-past that 3sg see them

'Ngozi came so that she will see them'

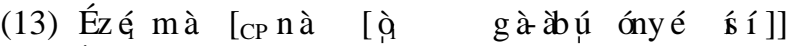

Ézé know that 3sg will pr.be person head

'Ézé knows that he $e_{i}$ will be a leader'

It has however been noted that what Uwalaka refers to as resumptive pronouns are indeed pronominal clitics "which are obliged to occupy the subject position of the constructions where they occur though, they are phonologically bound to a following a verb" (Anyanwu, 2005, p.161). Unlike a pronominal clitic, a resumptive pronoun is an overt (substantive) pronoun, which can occur in certain types of relative clauses and even in the non-dislocated part of a left dislocation (Trask, 1993). Resumptive pronouns occur in both English (she in14a, her in 14b) (Trask, 1993) and Igbo ( $y a$ in $15 \mathrm{a} \& \mathrm{~b}$ ) as the following examples show.

14 (a) That is the woman ${ }_{\mathrm{i}}$ [that I did not know if $s h e_{\mathrm{i}}$ was coming]

(b) Lisa $_{\mathrm{i}}$, I really like $h e r_{\mathrm{i}}$

15 (a) Nwókē áhù [ónyé anyi kwùrù nà yá gà-abia] bù ńnà ḿ

(Relative clause)

(Left dislocation) man that who we say-rv past that $3 \mathrm{sg}$. will pr.come be father my 'That man $_{\mathrm{i}}$ who we said (that he ${ }_{\mathrm{i}}$ ) would come is my father'

(b) Ézè

Eze, Ada see-rv past 3sg.

Eze $_{i}$, Ada saw him

The fact that the pronominal elements in (14-15) can be conjoined with substantive NPs is enough evidence that they themselves are also substantive pronouns. This is shown below (in $16-17$ ).

16 (a) That is the woman ${ }_{i}$ [that I did not know if she $e_{i}$ and John were coming] (Relative clause)

(b) Lisa $_{\mathrm{i}}$, I really like her and Mary (Left dislocation)

17 (a) Nwókē áhù [ónyé ànýi kwùrù nà yá nà Àdá gà-àbíá] bù ńnà me (Relative clause) man that who we say-rv past that $3 \mathrm{sg}$. and Ada will pr. come is father my 'That $\operatorname{man}_{\mathrm{i}}$ who we said that he $\mathrm{e}_{\mathrm{i}}$ and Ada would come is my father'

(b) Ézè ${ }_{\mathrm{i}}$, Àdá hùrù yá nà Ńgózíi ( Left dislocation)

Eze, Ada see-rv 3sg. and Ngozi

Eze, Ada saw him and Ngozi

Before going into the issue of the argument or pro-argument status of the Igbo PSCs, let us further examine some of their syntactic features which provide strengthening evidence of their clitic status.

\section{PSCS: SOME CROSS-LINGUISTIC INSIGHT}

Ndimele and Kari (1997) have also discussed PSCs in Degema, comparing the Degema subject clitics with verb agreement markers in pro-drop languages such as Italian and Spanish. They argue based on the role the subject clitics play (just like the verb agreement markers in Italian and Spanish) that Degema is also a pro-drop language. The Igbo PSCs functionally pattern like the Degema PSCs and also like the verb agreement markers in Italian and Spanish; hence it can be argued that Igbo is also a pro drop language. For the purposes of illustration, let us compare the Igbo constructions (18a-f) which contain both substantive subjects (lexical and pronominal) and PSCs with Italian (19), English (20) and Degema (21). The data are adapted taken from Ndimele and Kari (1997).

Igbo
18 (a) Ézè nà-àsú French
Eze aux pr.speak French
'Eze speaks French'
(c) Ó nà-àsú French
3sg CL aux pr. Speak French
'S/he speaks French'
(e) * Ézè ó nà-àsu French
Eze 3sg Cl aux pr. speak French
'Eze, he speaks French'
(g) Yá, [ ó nà-àsú French]

(b) Yá ${ }^{2}$ nà-àsú French

S/he aux pr. speak French

'S/he speaks French'

(d) *Yá ó nà-àsú French

S/he 3sg CL aux pr. speaks

(f) Ézè, [ó nà-àsu French ]

Eze 3sg CL aux pr. speak French

\footnotetext{
${ }^{2}$ The occurrence of yá in subject position as in (4b) is a variation that occurs in certain dialects. However, a coordination of yá with a substantive subject (e.g. Yá nà Àdá nà-àsú French) seems to be an option that cuts across most dialects.
} 
S/he 3sg CL aux pr. speak French

'S/he, s/he speaks French'

\section{Italian}

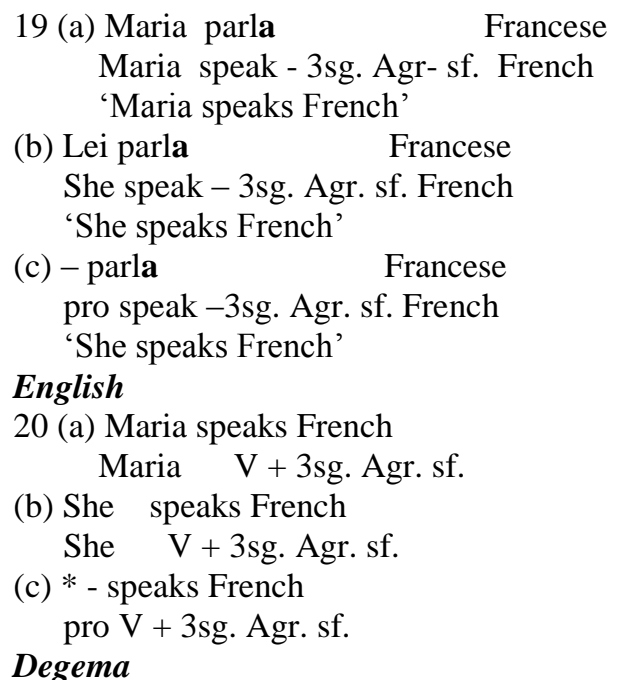
21 (a) Maria mó- kúwé French
Maria 3sg.CL-speak French
'Maria speaks French'

(b) Òyị mọ́- kứwẹ́ French

She 3sg.CL-speak French

'She speaks French'
(c) - mó-kúwé $\quad$ French
pro 3sg.CL-speaks French
'She speaks French'

Comparing the data in (18-21) shows certain striking differences and similarities among the languages in terms of the co- occurrence of substantive (lexical) NPs with verb agreement markers (for Italian and English) or pronominal subject clitics (for Igbo and Degema). Both Italian and English pattern closely in having verb agreement markers (suffixes) while Degema and Igbo allow PSCs. Italian, English and Degema pattern in the sense of allowing the co-occurrence of the verb agreement markers or PSCs with lexical or substantive pronouns. This option is not available in Igbo (18d \& 18e) except if the lexical NP or substantive pronoun is made a topic and adjoined to the left of a minimal clause (AGRsP) thus allowing the PSC to occur at the preverbal position (cf. 18f- 18g). Still, Italian, Degema and Igbo share the feature of having the phi-features of the non-substantive subject position to be recovered through verb agreement suffixes (for Italian, 19c) or PSCs (for Degema, 21c and Igbo, 18c). Thus, what is marked and recoverable through pronominal clitics in languages like Degema and Igbo is marked and recoverable through verb agreement suffixes in languages like Italian.

It is based on facts relating to the distribution of the PSC in Degema that Ndimele and Kari (1997) have argued that Degema is a pro-drop language (just as Italian and Spanish) since it allows the spec of AGRsP of finite clauses to be suppressed. They further observe that unlike Italian and Spanish, Degema has an impoverished verb agreement morphology, which is augmented by a rich clitic system. The PSCs in Degema behave like the verb agreement suffixes in Italian and Spanish. They encode phi-features (number and person) of the spec, AGRsP thus permitting pro and allowing the lexical NPs or substantive pronouns to delete in overt syntax.

Ndimele and Kari (1997) further stress that a rich system of verb agreement is not a necessary condition for licensing pro in the spec of AGRsP position as exemplified by Degema. Degema's verb morphology is not rich but has a rich clitic system; rich enough to encode the necessary phi-features so that a particular personal pronoun in the spec of AGRsP is recoverable from its associated pronominal clitic. Some languages such as Chinese and Japanese (Huang,1989, Eze, 1995) do not have rich agreement morphology but still allow the occurrence of pro in the spec, AGRsP of some finite clauses. On the other hand, German has a rich system of verb agreement and yet does not license pro in the spec of AGRsP (Ndimele and Kari 1997).

Following from the above observations, it is clear that the licensing of pro in the spec, AGRsP of some finite clauses is not tied to a robust and rich (verb) agreement system. Languages with an impoverished agreement system permit pro in the same position. Whereas in some languages (Italian and Spanish) the missing but understood subject (pro) is identifiable via verb agreement suffixes, in some others (Degema and Igbo) the understood subject is recoverable through pronominal subject clitics.

Igbo, unlike Degema, does not have a very rich clitic system. Every personal pronoun (singular and plural) in Degema has its corresponding subject clitic that can occur with its personal pronoun or alone. In Igbo, it is only the 
second and third persons singular as well as the non-specific personal pronouns that have subject clitics which, incidentally, cannot co-occur with their respective personal pronouns but can only occur alone. This points to the fact that Igbo is a pro-drop language as has been reported by Eze (1995).

Ndimele and Kari (1997) have made a categorization of language typology based on the pro-drop parameter as shown in the table below. They note that both Japanese and Chinese exemplify their category $\mathrm{C}$ with the characteristic features listed. To this group $\mathrm{C}$ we add Igbo.

\begin{tabular}{|l|l|l|}
\hline Category & Characteristics & Examples of Language \\
\hline A & $\begin{array}{l}\text { Languages with rich system of verb agreement } \\
\text { where licensing of pro is possible }\end{array}$ & $\begin{array}{l}\text { Romance languages (e.g. Italian and } \\
\text { Spanish) }\end{array}$ \\
\hline B & $\begin{array}{l}\text { Languages with rich system of subject clitic } \\
\text { agreement where licensing of pro is also possible }\end{array}$ & Degema \\
\hline C & $\begin{array}{l}\text { Languages with underived inflectional forms } \\
\text { exhibiting neither rich system of verb agreement nor } \\
\text { rich system of subject clitic agreement and yet the } \\
\text { licensing of pro is possible }\end{array}$ & Japanese, Chinese + Igbo \\
\hline D & $\begin{array}{l}\text { Languages exhibiting erratic or partial verb } \\
\text { agreement where pro licensing is not possible }\end{array}$ & English $^{3}$ \\
\hline
\end{tabular}

\section{The IgBo PSCs: Pro/ARgument StATUS}

Given the morphosyntactic status of the PSCs in Igbo and also the fact that it is restricted to the subject position of a sentence, it is important to investigate whether they can function syntactically as independent arguments or just as affixal agreement markers. Thus, the PSCs can be analyzed in two ways; they can be analyzed just like the English subject pronouns in which case, the PSCs are arguments in the spec of AGRsP as in (22).

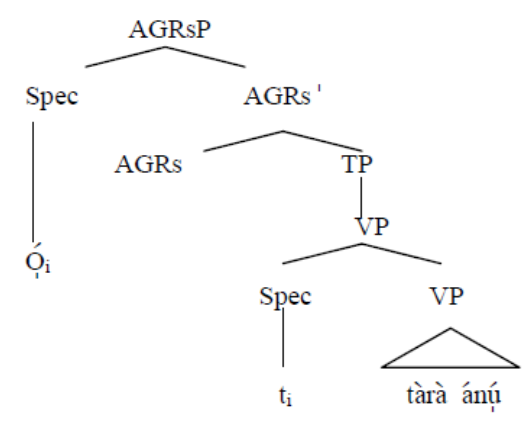

Based on (22), which represents the substantive argument analysis of PSCs, it can be argued that the PSC is generated at Spec, VP from where it raises to Spec, AGRsP for nominative case marking. Also, given the morphosyntactic status of the pronominal clitics, the argument analysis implies that the subject pronominal clitic having undergone a Spec-to-Spec move operation is at some point, lowered ${ }^{4}$ to AGRs by a syntactic operation or by a purely phonological process of cliticization. On the other hand, it can be argued that the PSC cannot occupy Spec, AGRsP argument position but just a mere functional element generated at AGRs which, identifies a null pronominal in subject position (cf. Rizzi, 1986). This type of analysis, the pro analysis as in (23), entails that the PSC is base generated at AGRs while its Spec, AGRsP is occupied by pro. Thus, the PSC is a spell- out of subject agreement features (cf. Campbell 1998).

\footnotetext{
${ }^{3}$ In English, the verb agreement suffix $-s$ is synchronically limited to the third person singular and as such seems to be at the verge of extinction. In Igbo, it can also be argued that the PSCs, which mark the second and third singular as well as the non-personal pronouns, are vestiges of a language, which once had a rich and robust pronominal clitic system

${ }^{4}$.It is important to note that in the Principles and Parameters approach adopted here feature lowering is not a permissible operation (Radford 1997).
} 


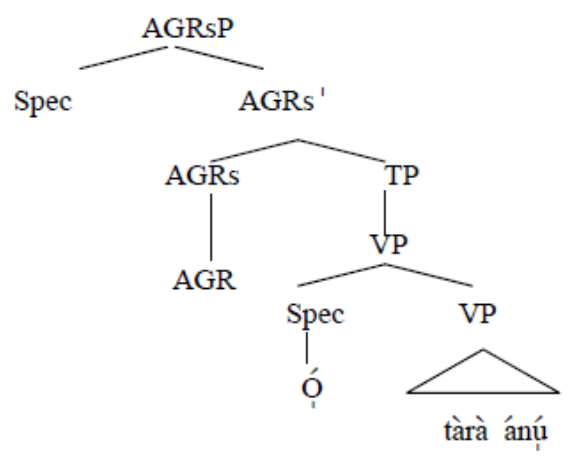

In line with the pro argument analysis, an Igbo sentence cannot have a PSC if the subject is already a substantive lexical NP. This prediction is true (24).

(24) * Ézè ó tàrà ánú

Eze 3sg.CL chew- rv past meat

Even in certain structures (e.g. interrogative (10), topicalized (18f)) where there is a juxtaposition of a substantive lexical NP and a PSC, the PSC surfaces as an overt trace of the substantive NP, which is moved and adjoined outside the minimal AGRsP.

The following section will further examine the morphosyntactic and morphophonological aspects as two independent dimensions. That is, it is either that the PSCs have substantive argument status and thus, are prohibited from cooccurring with overt lexical arguments or the PSCs are agreement markers (pros) and thus, do not count as substantive syntactic arguments but count as semantic arguments. We shall compare these two analyses and this we hope to do by examining the occurrence of the PSCs in Igbo syntactic causatives.

\section{IgBo PRonOMINAL SUBJECT Clitics AND SYNTACTIC CAUSATIVES}

'Causative' is term used to refer to a valence (NP) increasing mechanism. A causative construction is normally derived from a basic or non-causative construction. Though the basic and causative constructions each express some situation, it is only the causative one that has an additional different subject. It is the referent of this additional subject that brings about (or prevents) the state of affair described by the basic/non-causative construction (Comrie, 1985, Anyanwu, 2005). A causative verb is used in expressing a causative construction and such a causative verb may be a transitive verb (formed from an intransitive verb) or as found in some languages, a ditransitive verb (formed from a transitive verb). Cross-linguistically, three types of causatives have been identified. These are the syntactic (analytical) (consisting of a causative verb and complement clause), morphological (comprising of a causative verbal element and some other verbal element) and lexical (consisting of just an inherent causative verb). Causative constructions are exemplified by the following English and Igbo examples (Anyanwu, 2005) ${ }^{5}$.

\section{English}

(25) Mary makes Peter smile a lot

(26) Mary enslaved her husband

(27) Mary broke the plates

Igbo

(28) Ézè mèrè Àdá èrié ji

Eze cause/make-rv past Ada E-pr.eat E-suff. yam

'Eze caused/made Ada eat yam'

(29) Ézè médàrà éféré áhù

Eze cause/make fall-rv past plate that

'Eze caused that plate to fall'

(30) Ézè kụ̀àrà éféré áhù

Eze hit-break plate that

'Eze broke that plate'

From the English and Igbo examples, it is obvious that a causative construction (whether syntactically, morphologically or lexically based) has one unique feature; the feature that an NP is specified as being responsible for causing or (not causing) a given state of affairs. In the syntactic causative, the causative verb mé 'cause/make' takes an AGRsP complement. This is true regardless of whether the subject of the complement clause is a substantive NP, an accusative pronoun or a PSC. Thus, the causative construction in Igbo involves a reduced clause complement to the causative verb mé as in (28). The reduced clause complement is obviously an AGRsP for a number of reasons. First,

\footnotetext{
${ }^{5}$.Igbo causatives have been discussed extensively in Anyanwu (2005).
} 
unlike a full clause complement where an overt COMP (lementizer) is normally present (31), no such COMP is required in the causative construction (32) and this shows that the COMP is absent; the clause complement is not a complementizer projection.

(31) Ézè kwùrù (nà) ó rìri ji

Eze say-past that $3 \mathrm{sg}$.CL eat -rv past yam

(32) Ézè mèrè (*nà) ó ríe ji

Eze cause/make that 3sg.CL eat E-suff. yam

Secondly, the embedded clause complement can be negated independently and this suggests the presence of the NEG (ative) (P) hrase within it (33).

(33) Ézè mèrè ò ríghíi ji

Eze cause/make-past 3sg.CL eat NEG suff. Yam

'Eze cuased/made him/her not to eat yam'

Also the subject (causee) of the complement clause can be a pronominal clitic or an accusative pronoun as in (34) and (35) respectively.

(34) Ézè mèrè ó táá ánū

Eze cause/make-past 3sg.CL chew-suff. meat

'Eze caused/made him/her eat meat'

(35) Ézè mèrè yá àtáá ánū

Eze cause/make-past pr. chew meat

Eze caused/made him/her eat meat

It can also obviously be observed that there is no semantic difference between (34) and (35) and it is therefore important to know whether or not (34) and (35) have different structures. On the surface, both (34) and (35) seem to have essentially the same structure as shown below in (36) and (37) respectively where the causative verb in each case takes a clause complement, which can be negated independently. Note that independent negation is possible only within AGRsP (Campbell, 1989, 1995). Whereas the causee in (34) is a pronominal clitic, in (35), it is a substantive pronoun, an exceptionally case-marked subject (not a matrix object). While yá in (35) can be substituted with a lexical NP (e.g. Àdá) without any loss of grammaticality (36), this is not so with o in (34) as shown in (37).

(36) Ézè mèrè Àdá àtáá ánú

Eze cause/make-rv past Ada pr. chew E-suff. meat

'Eze caused/made Ada eat (some) meat'

(37) * Ézè mèrè Àdá táá ánú

Eze cause/make-rv past Ada chew E-suff. meat

From (34) and (35), it can be observed that other than the morphological shape of the causee (yá or o) and perhaps case, there seems to be no reason to argue for a structural difference between the two constructions. It is however, very crucial to account for why the two different pronominal forms that are formally distinct but semantically identical occur in identical environments. Being able to account for the alternation is central to choosing the substantive argument or pro argument analysis of Igbo pronominal clitics. However, the difference in morphological shape between the two pronominal elements as either a pronominal clitic o in (34) or a substantive pronoun yá in (35) cannot be attributed to a difference in structural relations between them and the subjects of their matrix causative verbs.

Based on Condition B of Chomsky's (1981) binding theory, a pronominal element (overt pronoun or pro) must not corefer with a constituent within the smallest clause that contains the pronominal element and its governor (its binding domain). In both (34) and (35), the pronominal causee o or yá cannot co-refer to Ézè, the matrix subject. This is an indication that the binding domain of the pronominal causee in the embedded Spec, AGRsP is the matrix AGRsP (clause) in both cases and the governor in each case is the matrix causative verb, mèrè. Thus, facts from binding have shown that in (34) and (35) the matrix causative verb governs each causee irrespective of its morphological shape. These binding facts as they relate to (34) and (35) differ from the one in (38) for instance, where a substantive pronoun yá is governed within the embedded AGRsP which of course is its binding domain. Since Ézè in (38) is outside the binding domain of yá, there is therefore no violation of Condition B of the binding theory if yá and Ézè co-refer.

(38) Ézè chè nà yá gà-àbíia

Eze thinks that he will come

'Eze thinks that he will come'

Obviously, the difference in the morphological spell-out of the causee in (34) and (35) correlates with a difference in the structural position occupied by each of them. Thus, accounting for this alternation basically entails positing distinct structures for (34) and (35). For (34), there are two possibilities; one in which the pronominal clitic is in Spec, AGRsP and is therefore, assigned a nominative case (assuming that the substantive argument analysis is correct (39)) or one in which there is a pro in Spec, AGRsP which has the PSC as its spell-out in AGR (if the pro argument analysis is correct (40)). 


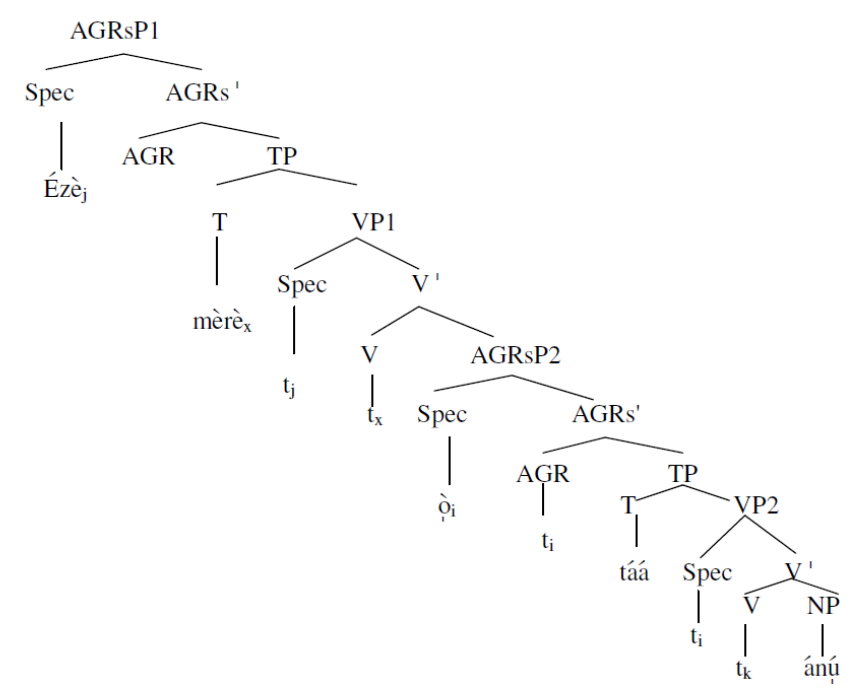

(40)

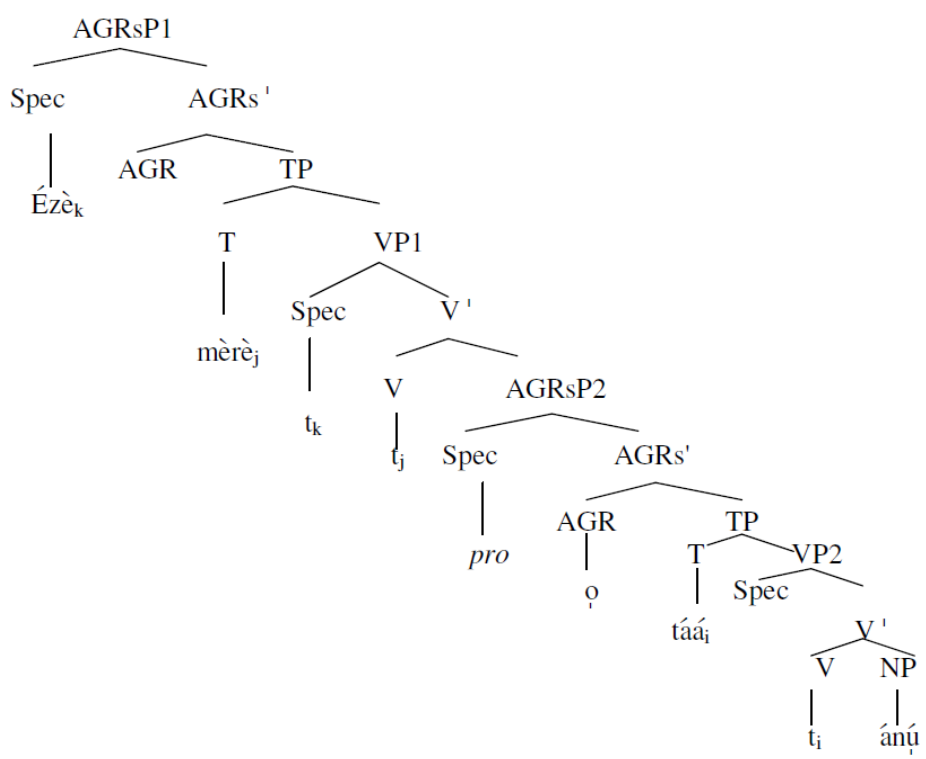

A substantive argument analysis for the PSCs in Igbo such as (39) would be ill motivated. Given their morphosyntactic status as clitics, the PSCs (as has been argued for Degema PSCs (Ndimele and Kari, 1997)) are not generated at Spec, VP (a position for substantive NPs that can be conjoined, topicalized, etc.) as shown in (39) but at the head of AGRs' ', AGR. An analysis such as (39) assumes that the PSC raises from the embedded Spec, VP to the embedded Spec, AGRsP via AGR, and a case of Spec-Head-Spec movement. A pro argument analysis such as (40) is well motivated. The pro in the embedded Spec, AGRsP is identified by the PSC generated at AGR. This shows that the AGR must spell-out the features of Spec, AGRsP if Spec, AGRsP is pro. This is expected given the fact that such a configuration is where subject agreement applies. The verb of the embedded VP obligatorily raises ${ }^{6}$ to $\mathrm{T}$ (ense) for T finite features and this ensures that the V (erb) occurs to the right of the PSC. The association between the PSC and the $\mathrm{V}$ ensures that the PSC receives nominative case properties associated with the pro in Spec, AGRsP in fulfillment of Extended Projection Principle (EPP) (Chomsky 1982) and theta-marking condition of subjects (Burzio, 1981). For (35), its tree structure representation is (41). Unlike in the pro argument analysis of (40) the causee yá in (41) is a substantive pronoun and indeed subject to the syntactic processes of substantive arguments. Whereas the causee yá raises overtly from Spec, VP2 to Spec, AGRsP and covertly to Spec, AGRoP for Exceptional Case Marking (ECM), no such raising affects the PSC in (40).

\footnotetext{
${ }^{6}$ Again, the Igbo orthographic convention/representation, which separates the PSC and a following verbal element, does not reflect the phonetic/phonological affinity between the two
} 


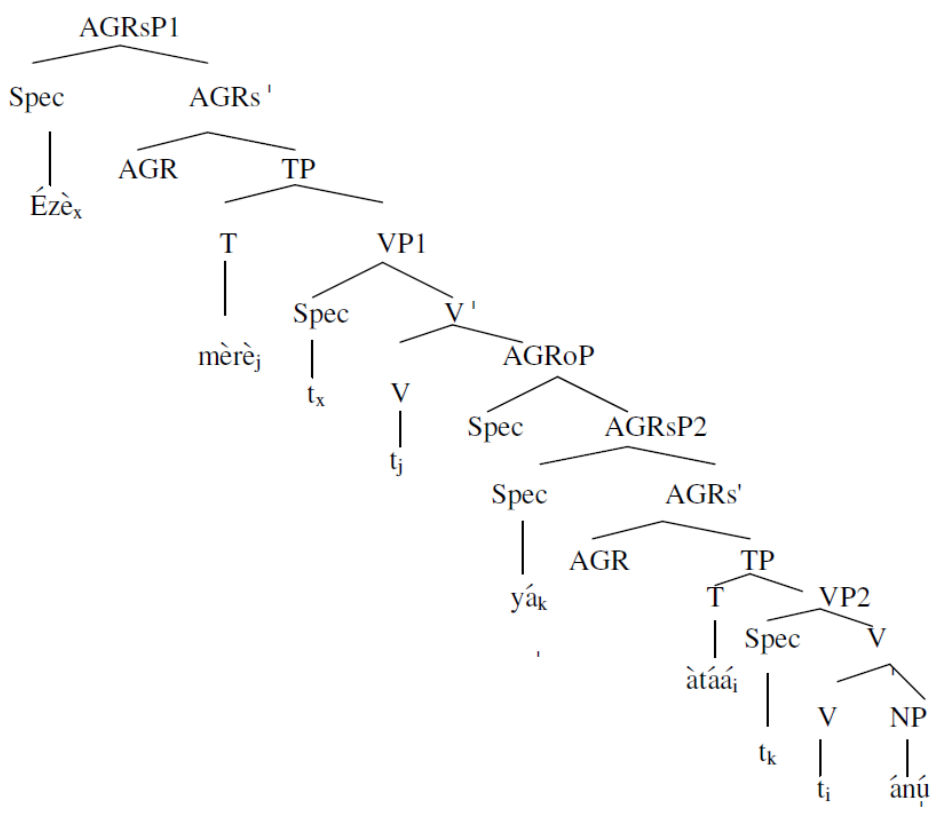

Further evidence against a substantive argument status of the PSC in Igbo comes from a Universal Grammar feature which requires an affixal element and its host to form a syntactic unit. Thus, PSC and its host form a syntactic constituent. If the PSC is however analyzed an substantive argument, it then follows that it would have to adjoin to AGR thus resulting in a structure such as $(42)^{7}$

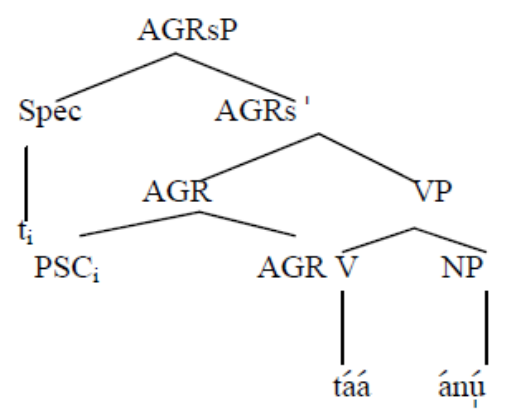

As can be seen in (42), the moved PSC does not c-command ${ }^{8}$ its trace since the first category dominating the PSC, AGRs ' does not dominate Spec, AGRsP. Therefore, the trace in Spec, AGRsP is not antecedent governed, a violation of the Empty Category Principle (ECP) (Chomsky, 1986) which again, makes the substantive argument analysis for pro untenable.

\section{CONCLUSION}

In this paper we have been discussing PSCs in Igbo. Using certain syntactic evidence (strict adjacency to the main or auxiliary verb, modification, topicalization, coordination, etc.), we have shown that the PSCs in Igbo are not substantive pronouns. With respect to whether the PSC can occupy a pro argument or a substantive argument postion, we have argued, appealing to evidence from causative constructions that the pro argument analysis for the PSCs in Igbo is superior to the substantive argument analysis.

\section{REFERENCES}

[1] Anyanwu, O.N. (2005). The syntax of Ngwa Igbo causatives: a minimalist account. The Linguistic Association of Nigeria. Land Marks Series 2.

[2] Borer, H. (1986). The syntax of pronominal clitics In Borer (ed.). Syntax and semantics. 19, 1-11. Academic Press, Inc.

[3] Burzio, L. (1981). Intransitive verbs and Italian auxiliaries. Unpublished PhD Dissertation. MIT.

[4] Campbell, R. (1989). The grammatical structure of verbal predicates. PhD Dissertation. UCLA.

[5] Campbell, R. (1995). Inflectional domains and comp features. Lingua 96:119-138.

\footnotetext{
${ }^{7}$ We have ignored some other projections, illustrating only with the ones relevant for the purpose.

${ }^{8}$ We assume the definition of c-command where a category X c- commands another $\mathrm{Y}$ only if the first category dominating $\mathrm{X}$ also dominates $\mathrm{Y}$.
} 
[6] Campbell, R. (1998). A note on subject clitics in Akan. Studies in African linguistics. 27: 49-66.

[7] Chomsky, N.(1981). Lectures on government and binding. Dordrecht: Foris.

[8] Chomsky, N. (1982). Some concepts and consequences of the theory of government and binding. Cambridge, Mass: MIT Press. Chomsky, N .Barriers. Cambridge, Mass: MIT Press.

[9] Comrie, B. (1985). Causative verb formation and other verb-deriving morphology. In Shopen, T.(ed.). Language typology and syntactic description. Cambridge: Cambridge University Press. 3: 309-348.

[10] Emenanjo, E.N. (1978).Elements of modern Igbo grammar. Ibadan: Oxford University Press.

[11] Eze, E (1995). The forgotten null subject of Igbo. In Akinlabi, A. (ed.). Theoretical approaches to African linguistics, 45-81. New Jersey: Africa World Press.

[12] Green, M.M. \& G.E. Igwe. (1963). A descriptive grammar of Igbo. Berlin, Akademic, Verlac and London: Oxford University Press.

[13] Huang, C-T. J. (1989). Pro-drop in Chinese: a generalized control. In Jaeggli, O., \& K.J. Safir (eds.). The null subject parameter, 185-214. Dordrecht: Kluwer.

[14] Jaeggli, O. (1981). Topics in Romance Syntax. Dordrecht and Cinnaminson, New Jersey: Foris Publiations.

[15] Katamba, F. (1993). Morphology. London: Macmillan.

[16] Ndimele,O-M \& E. Kari. (1997). A minimalist account of pro-drop in Degema. Nigerian Language Studies. 5.44-55.

[17] Nwaozuzu, G.I. (2007).Erroneous assumptions in the description of some aspects of indigenous Nigerian languages: The case of the unspecified pronominal element in Igbo. Onitsha: Africana-Fep Publishers Limited. 15-27.

[18] Radford, A. (1997). Syntax: a minimalist introduction. Cambridge: Cambridge University Press.

[19] Rizzi, L. (1986). Null objects in Italian and the theory of pro. Linguistic Inquiry 17, 501-557.

[20] Trask, R.T. (1993). A dictionary of grammatical terms in linguistics. London \& New York: Routledge.

[21] Uwalaka, M.A. (1995). The resumptive pronoun strategy in Igbo. In Emenanjo, E.N. and O-M. Ndimele(ed.). Essays in Honour of Kay Williamson. Aba: NINLAN Books.

[22] Zwicky, A.M. (1977). On clitics. Bloomington: Indiana University Press.

Ogbonna Anyanwu is a Senior lecturer at the Department of Linguistics and Nigerian Languages, University of Uyo, Nigeria. He obtained his MA and PhD degrees from the University of Port Harcourt, Nigeria. His research interests include phonology, morphology, Igbo syntax and the development of non-major Nigerian languages. He has published mainly in these areas. 